\title{
25 jaar Aanwijzingen voor de regelgeving, reden voor een feestje?
}

\author{
D.R.P. de Kok
}

\section{Inleiding}

Zoals militairen het Handboek voor den Soldaat kennen en gelovigen de Bijbel, zo kennen wetgevingsjuristen de Aanwijzingen voor de regelgeving: het boek dat spreekwoordelijk op het nachtkastje ligt en waaruit ogenschijnlijk naar willekeur kan worden geciteerd. Zo weet menig wetgevingsjurist zich van andere bevolkingsgroepen te vervreemden door te stellen dat "na "een" "als bedoeld" volgt en na "de" "bedoeld" of "genoemd". Sinds 1 januari 1993, toen de Aanwijzingen voor de regelgeving (hierna: Aanwijzingen) in werking traden, ${ }^{1}$ behoren zij tot de 'persoonlijke standaarduitrusting'2 van de wetgevingsjurist. Bij zijn aantreden krijgt hij een exemplaar uitgereikt. ${ }^{3}$ En vervolgens vormen de Aanwijzingen een vast baken voor dagelijkse vragen als 'Hoe moet ik ook al weer een inwerkingtredingsbepaling formuleren?', 'Hoe zat het nou met voor- en nahang?' en 'Hoe regel ik toch die samenloop van wetsvoorstellen?'

\section{5 jaar Aanwijzingen}

2018 is dus een jubileumjaar. Fijnproevers zullen echter opmerken dat de Aanwijzingen al langer bestaan. Want vóór de inwerkingtreding van deze 'moderne' Aanwijzingen was er sprake van aparte aanwijzingen voor de wetgevingstechniek naast allerlei andere aanwijzingen en richtlijnen, waaronder de Aanwijzingen inzake terughoudendheid met regelgeving. Konijnenbelt gaat hier in zijn bijdrage voor dit themanummer nader op in. De operatie die in 1992 werd ingezet,

* De auteur is naast redacteur van RegelMaat ook lid van de werkgroep Aanwijzingen voor de regelgeving. Hij schrijft dit redactioneel artikel mede vanuit die hoedanigheid.

1 Regeling van de minister-president, Minister van Algemene Zaken, van 18 november 1992, houdende vaststelling van de Aanwijzingen voor de regelgeving (Stcrt. 1992, 230). Daarmee steken de Aanwijzingen natuurlijk wel schril af bij het Handboek voor den Soldaat (1937) en de Bijbel (exacte publicatiedatum onbekend, maar kort na het begin van de jaartelling).

2 Zo schrijft minister-president Lubbers in de toelichting bij bovengenoemde publicatie: 'Een goede wetgevingsambtenaar rekent de Aanwijzingen tot de persoonlijke standaarduitrusting.' De vergelijking met het Handboek voor den Soldaat is dan ook snel gemaakt.

3 Ook hierover is minister-president Lubbers duidelijk in de toelichting: 'De nieuwe Aanwijzingen zullen in ruime mate worden verspreid over de ministeries. Als uitgangspunt daarbij geldt dat iedere wetgevingsambtenaar over de Aanwijzingen kan beschikken en dat ook beleidsdirecties beschikken over de voor hen relevante onderdelen.' Te vrezen valt dat het laatste deel van de vorige zin veel minder goed wordt nageleefd dan het eerste deel ervan ... 
beoogde aan deze versnippering een eind te maken door één integraal document te maken, waarin alle aspecten die bij wetgeving een rol moeten spelen, werden samengevoegd. Hiermee werd een vervolg gegeven aan de kort daarvoor verschenen nota Zicht op wetgeving. ${ }^{4}$ In die nota werd voor het eerst een integraal overzicht gegeven van de kwaliteitsaspecten die voor de totstandkoming van wetgeving van belang zijn en waarop de toetsing door het Ministerie van Justitie gebaseerd werd en (onder de opvolgers van dat ministerie) nog steeds is. Daarbij ging het zowel om aspecten die in de inhoudelijke aanwijzingen zijn uitgewerkt, als om aspecten als de eenvoud, duidelijkheid en toegankelijkheid, waarvoor de meer technische aanwijzingen zijn opgesteld. De Aanwijzingen zijn daarmee een onderdeel geweest van de professionalisering van het vak van wetgevingsambtenaar die met Zicht op wetgeving in gang is gezet en die ook heeft geleid tot andere (wetgevings)instrumenten als het Draaiboek voor de regelgeving en het Integraal afwegingskader voor beleid en regelgeving (IAK), en de oprichting van de Academie voor Wetgeving.

De Aanwijzingen zijn vervolgens inspiratiebron geweest voor de Aanwijzingen voor de decentrale regelgeving, die later zijn opgevolgd door de 100 Ideeën voor de gemeentelijke regelgever. Ook voor de Antilliaanse regelgeving zijn op basis van de Aanwijzingen kaders ontwikkeld. En ook op Europees niveau is er een Interinstitutionele schrijfwijzer tot stand gekomen waarbij mede is gekeken naar de Aanwijzingen.

\section{Karakter van de Aanwijzingen}

De Aanwijzingen hebben het karakter van een interne regeling van de ministerpresident. Deze is bindend voor 'de ministers en staatssecretarissen en de onder hen ressorterende dienstonderdelen en personen die bij de voorbereiding en vaststelling van regelingen zijn betrokken' (Ar 1.2, eerste lid). 'Afwijking (...) is slechts toegestaan, indien onverkorte toepassing daarvan uit een oogpunt van goede regelgeving niet tot aanvaardbare resultaten zou leiden' (Ar 1.2, tweede lid). De toelichting bij Ar 1.2 vermeldt nog dat 'het aanbeveling verdient' dat de StatenGeneraal met de Aanwijzingen rekening houden. De Aanwijzingen hebben betrekking op 'regelingen die onder ministeriële verantwoordelijkheid tot stand komen en, voor zover uitdrukkelijk aangegeven, op verdragen, bindende besluiten van instellingen van de Europese Unie en andere besluiten van volkenrechtelijke organisaties' (Ar 1.1). Waarbij onder 'regelingen' worden verstaan algemeen verbindende voorschriften (wetten, algemene maatregelen van bestuur, ministeriële regelingen en regelingen van zelfstandige bestuursorganen; zie Ar 2.18), interne regelingen en beleidsregels (Ar 1.3, eerste lid). 


\section{De tiende wijziging}

Het zilveren jubileum van de Aanwijzingen is opgeluisterd door de vaststelling van de tiende wijziging ervan. Met deze wijziging zijn de Aanwijzingen integraal herzien en opnieuw vastgesteld. ${ }^{5}$ Dit is anders dan de voorgaande negen wijzigingen, die actualiseringen, verbeteringen en inhoudelijke toevoegingen op specifieke onderdelen betroffen, en alle het karakter hadden van aanpassingen van de tekst uit 1992. De tiende wijziging is per 1 januari 2018 in werking getreden, precies 25 jaar dus na de eerste inwerkingtreding. Die planning lijkt hierdoor te zijn ingegeven, maar de eerlijkheid gebiedt te erkennen dat sprake is van toeval. Aan de tiende wijziging is al sinds 2011 gewerkt en oorspronkelijk niet met het oogmerk er pas in 2018 mee klaar te zijn. De integrale herziening kostte simpelweg meer tijd dan voorzien.

\section{Themanummer: 25 jaar Aanwijzingen, reden voor een feestje?}

De vraag die in dit themanummer centraal staat, is of het 25-jarig bestaan reden is voor een feestje. Uit het feit dat we van dit themanummer een 'dubbeldikke' editie hebben gemaakt die twee normale edities (2018/1 en 2018/2) combineert en daarmee, voor het eerst in de geschiedenis van dit tijdschrift, de verschijningscyclus doorbreken, kan de lezer waarschijnlijk wel het antwoord van de redactie op die vraag afleiden. Maar het is uiteraard niet aan de redactie en al zeker niet aan de bevooroordeelde schrijver van dit redactioneel artikel om het antwoord op die vraag te geven; dat is aan de lezer zelf. Om hem of haar daarbij te helpen laten wij maar liefst zeven auteurs aan het woord, verdeeld over zes bijdragen.

De eerste bijdrage is van de hand van Vester. Hij is als voorzitter van de werkgroep Aanwijzingen voor de regelgeving als geen ander in staat om de tiende wijziging toe te lichten. Dat vormt dan ook het hoofdbestanddeel van zijn artikel. Hij bespreekt de totstandkoming ervan alsmede de inhoud, waarbij een groot aantal aanpassingen inzichtelijk wordt behandeld. Maar hij gaat ook nader in op de betekenis van de Aanwijzingen en categoriseert de verschillende typen aanwijzingen. Ook gunt hij ons een blik in de toekomst: welke ontwikkelingen ziet de werkgroep Aanwijzingen op zich afkomen en zullen leiden tot nieuwe wijzigingen?

Dan volgen twee rechtsvergelijkende onderzoeken:

- Stip zet de Nederlandse Aanwijzingen af tegen soortgelijke documenten in Duitsland, Zwitserland, het Verenigd Koninkrijk, de Europese Unie, Canada en de Canadese provincie Brits-Columbia. Zij vergelijkt de verschillende documenten op algemene aspecten als juridische status, omvang en aandacht voor de wetgevingstechniek en categorie-indeling. Maar ze gaat ook een stap verder door nader te onderzoeken hoe de specifieke onderwerpen 'beknoptheid'

5 Besluit van de Minister-President, Minister van Algemene Zaken, van 22 december 2017, houdende vaststelling van de tiende wijziging van de Aanwijzingen voor de regelgeving (Stcrt. 2017, 69426). 
en 'het voorkomen van dubbelzinnigheid' zijn uitgewerkt in de onderzochte landen.

- Konijnenbelt behandelt, na een beschouwing over de totstandkoming van de Nederlandse Aanwijzingen, de 'gidsen voor het wetgeven' in de landen België, Luxemburg, Frankrijk, Italië en Spanje. Voor al deze landen bespreekt hij de aard van die gidsen en gaat hij ook in op de wetgevingsculturen waar die gidsen mee verbonden zijn. Zijn bijdrage mondt uit in een aantal conclusies en aanbevelingen voor de Nederlandse Aanwijzingen.

Borman, die mede aan de wieg stond van de Aanwijzingen in 1992, gaat in zijn artikel, het vierde in dit themanummer, in op de naleving van de Aanwijzingen. Daartoe heeft hij een concreet onderzoek gedaan naar de mate waarin ministeriele regelingen die aan het eind van 2017 zijn gepubliceerd de Aanwijzingen hebben gevolgd. Hij heeft daarbij concreet gekeken naar de meer technische aanwijzingen. Hij trekt de vergelijking met een soortgelijk onderzoek van Voermans en Eijlander van vijftien jaar geleden. Dat levert diverse inzichten op over de ontwikkeling in de naleving en over de wijze waarop tegenwoordig met de Aanwijzingen wordt omgegaan.

De vijfde bijdrage is geschreven door twee wetgevingsjuristen van het Ministerie van Infrastructuur en Waterstaat, Oldenziel en De Vos. Het artikel gaat in op de Leidraad wetgevingskwaliteit omgevingswetgeving die is ontwikkeld voor de totstandkoming van de Omgevingswet en bijbehorende uitvoeringsregelgeving. Daarin zijn vuistregels opgenomen die veelal een nadere concretisering vormen van - vrij globaal geformuleerde - aanwijzingen uit de Aanwijzingen voor de regelgeving. Denk aan aanwijzingen over het streven naar duidelijkheid en eenvoud, het zo veel mogelijk volgen van het normale spraakgebruik en beknopt formuleren. Zij doen aanbevelingen over opname van sommige van de ontwikkelde vuistregels in de Aanwijzingen omdat ze algemeen toepasbaar zijn.

De zesde en laatste bijdrage is van Corver. Hij heeft zich in zijn tijd als ambtenaar bij de Vereniging van Nederlandse Gemeenten beziggehouden met de 100 Ideeën voor de gemeentelijke regelgever en schrijft zijn artikel daarover. Hij gaat in op de totstandkoming en de aard van de 100 Ideeën en trekt daarna een vergelijking tussen dit instrument en de Aanwijzingen. Deze vergelijking mondt uit in drie verschillen, twee kritische noten en één aanbeveling voor de Aanwijzingen.

$\mathrm{Al}$ met al een rijkgeschakeerd palet aan artikelen. Dit past ook bij het belang van de Aanwijzingen voor het bevorderen van de wetgevingskwaliteit. Want ondanks het feit dat er inmiddels ook andere instrumenten voor de wetgevingsjurist zijn verschenen - het Draaiboek voor de regelgeving, het IAK, de Handleiding Wetgeving en Europa -, blijven de Aanwijzingen het belangrijkste instrument. Dat komt door het verplichtende karakter ervan én door het feit dat ze de wetgevingsjurist helpen bij de beantwoording van tal van, soms hele praktische, vragen. Vester gaat hier in zijn bijdrage nader op in. De werkgroep Aanwijzingen is continu bezig om relevante ontwikkelingen bij te houden en neer te laten slaan in de Aanwijzingen. $\mathrm{Nu}$ de tiende wijziging net is gepubliceerd, werkt zij alweer aan de 
elfde wijziging. Vester gaat in zijn bijdrage ook in op de beoogde inhoud daarvan. Op die manier zijn de Aanwijzingen een 'levend' document en staat niets eraan in de weg om over 25 jaar het vijftigjarig jubileum te vieren met een nog dikker feestnummer van RegelMaat! 